\title{
CORRECTION
}

\section{Correction to: Formation by silicate-fluoride + phosphate melt immiscibility of REE-rich globular segregations within aplite dikes}

\author{
Charles R. Stern ${ }^{1}$. Julien M. Allaz ${ }^{1,3} \cdot$ Markus B. Raschke $^{2} \cdot$ G. Lang Farmer ${ }^{1} \cdot$ M. Alexandra Skewes ${ }^{1}$. Jeremy T. Ross ${ }^{1,4}$
}

Published online: 10 September 2018

๑) Springer-Verlag GmbH Germany, part of Springer Nature 2018

\author{
Correction to: \\ Contributions to Mineralogy and Petrology (2018) \\ 173:65 \\ https://doi.org/10.1007/s00410-018-1497-7
}

In the version of the paper originally published the current address of author Jeremy T. Ross was given incorrectly as Untied Status Marine Corp, 3351 Onslow Drive, Camp Lejeune, NC 28547, USA.

The correct address is United States Marine Corp, 3351 Onslow Drive, Camp Lejeune, NC 28547, USA.

The original article can be found online at https://doi.org/10.1007/ s00410-018-1497-7.

Charles R. Stern

Charles.Stern@colorado.edu

1 Department of Geological Sciences, University of Colorado, Boulder, CO 80309-0399, USA

2 Departments of Physics, Chemistry, and JILA, University of Colorado, Boulder, CO 80309-0390, USA

3 Present Address: ETH Zurich Institute für Geochemie und Petrologie, 8092 Zurich, Switzerland

4 Present Address: United States Marine Corp, 3351 Onslow Drive, Camp Lejeune, NC 28547, USA 